\title{
MICROBIOLOGICAL TREATMENT OF LIQUID WASTES PRODUCED DURING WET STORAGE OF SUGAR CANE BAGASSE IN PAPER PULP INDUSTRY
}

\author{
(Received:12.8.2006)
}

\author{
By \\ R.I. Refae \\ Agricultural Microbiology Department, Faculty of Agriculture, Cairo University, Giza, Egypt
}

\begin{abstract}
Wet storage of bagasse used in the paper pulp industry produces considerable amounts of liquid wastes that can pollute the environment, particularly in the absence of the suitable treatment. Wastewater samples were analyzed for chemical oxygen demand (COD), 5-days biological oxygen demand $\left(\mathrm{BOD}_{5}\right)$, $\mathrm{pH}$, total suspended solids (TSS), ash, nitrogen, phosphorus and microbial counts. Low records of microflora of $c a .10^{3} \mathrm{cfu} \mathrm{ml}^{-1}$ and $\mathrm{pH}$ of 4.5 were estimated while concentration of organic substances was high (COD equals $3472 \mathrm{mg} \mathrm{l}^{-1}$ ). The $\mathrm{BOD}_{5}$ reached $2700 \mathrm{mgl}^{-1}$ which corresponded to $77.8 \%$ of the COD value. Nitrogen and phosphorus concentrations were almost 20 and $2 \mathrm{mg} \mathrm{l}^{-1}$, respectively representing a poor COD: N: P ratio of 1736: 10: 1 . Therefore, the optimal environmental conditions required for biological wastewater treatment were studied. The activity of microflora in the wastewater was enhanced which in turn stimulated the biodegradation of organic substances. The percentage of COD reduction appeared to be depended on the COD: $\mathrm{N}$ : $\mathrm{P}$ ratio and the $\mathrm{pH}$. Results showed that this ratio should be modified to be suitable for nutrition and enrichment of microorganisms in the wastewater and the necessity of addition of 5\% activated sludge from wastewater treatment plant as a source of acclimatized microorganisms. The best results were obtained when the COD: N: P ratio was adjusted to 1017: 16: 4, where the organic matter removal efficiency was $97 \%$. The suspended solids in the effluent could be reduced to $40.7 \mathrm{mg} \mathrm{l}^{-1}$, which corresponded to $8.9 \%$ of that of the influent. Maintaining the $\mathrm{pH}$ constant within a range of 7 during the treatment resulted in acceleration of the COD reduction i.e 68.2\% reduction after 2 days compared to $33 \%$ without $\mathrm{pH}$ control. $\mathrm{BOD}_{5}$ was reduced to $54.9 \mathrm{mg} \mathrm{\textrm {l } ^ { - 1 }}$. The addition of a composite bacterial inoculant was efficient for COD reduction, since $80 \%$ of the COD was degraded within one day. However, considering the final COD content, activated sludge appeared to be more effective. The aerobic treatment of this wastewater would render it suitable to be discharged without environmental problems. These results show that there is potential for the plant to use such a treatment for treating its wastewater for discharge or reuse. The final water quality would be acceptable for dilution and pulp washing applications.
\end{abstract}

Key words: activated sludge, bagasse, biological wastewater treatment, $B O D_{5}, C O D$, paper pulp industry, wet storage.

\section{INTRODUCTION}

There are 11 facilities of pulp and paper industries in Egypt producing 41 million $\mathrm{m}^{3}$ of wastewater per year (Ezz, 2003). Thus, discharge of such high quantities without adequate treatment can pollute the environment. Among raw materials used for paper industry is the sugar cane bagasse (outer stalk sugarcane). It is the fibre left over after extracting sugar from sugarcane. The bagasse obtained from the sugar mill, having 3-4 $\%$ residual sugars is stored in the bagasse yard by wet bulk storage method (Atchison, 1971) for a period of 3-9 months. During storage, the bagasse is kept under wet conditions by spraying water over bagasse pile to preserve bagasse quality. Reclamation water, used to recover bagasse from storage, has a $\mathrm{pH}$ of approximately 4 and a population of acidogenic bacteria due to the acidogenic conditions under which bagasse is preserved during storage. This stream also contains suspended organic and inorganic materials (Hunt and Pretorius, 2000). With the everincreasing focus on the environmental issues and the development of more stringent laws, the 
prospect of minimiring water crnsumption and racaverieg wautewater for neuse has became inore epcoiing to induatry. The mill in question in inveatigating the possihility of sliminating elolewase discharge. To achiese this poal, if if mesessary to treat a waskewiter ntram for muse in the mill. One of the mechoda cumently med for dinposal of such wastewater is to discharge the efllicret firecthy. Hiolopical wastereater trecatment iocludes a variefy of eethode which ave used by pulp and paper mills for purifyine their wastewater (such as the activaind shafee method) in which nathind microonganiame decompose the grganic subutance. The arganiums constinute o natrient cycle meisb consisting of hacteria and protoma. Sach meibod muluces the bioloyical oxygen demand (BOD,) by mure than 95 S and femoves ce. 50 st of the orpanic campounds from effluent. Melimirary imestigations nuled out the posibility of using etewventionat biological treatencen, chemical precipiation ant acid induced lignia provipication as powaible wastrwater trejencet metheda (Hint and Preseries, 1999 ). Buth anocrotic and acrobic system are voed to ineat wantrouter (Loe $\alpha$ il, 1999, litwener, Kertidas of of (1994) foumd the

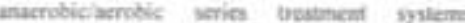
vostuce better final effluent at lower capital and punaing pasts than anserooic or actobic peocesuca se their awn.

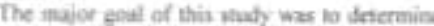

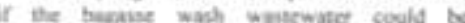
bieloyicalfy tranet to mest beth the intermptional and local standands for discharging.

\section{MATERIALS AND METHODS}

\subsection{Cutture media}

Cellulose aye (Allin. IP9) was sied foe muaceration of the cellutytic bacteria. if is

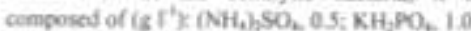
$\mathrm{KCZ}, 0.5$; $\mathrm{MgCl}, 6 \mathrm{H}_{2} \mathrm{O}, 0.5$; yeast cutract. 0.5.

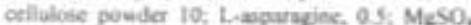
0.2: $\mathrm{CaCT}_{3}$ 0.1; agar, 20 and pit 7,0. The plate. were inspetind visually for a roes of clearing indicatios of ite comaumptice of imoluble eetlebse. Far enumerstion of yents and molds both Sabournut Deatrone Ayz (Oxnid, I8s3) fs) "septime, 10: deatruser, 40. agte, 15 and $\mathrm{pH} 5.8$. and Crapel Des Agur (Oneid, 1985) (s $\mathrm{r}^{\prime}$ $\mathrm{NaNO}_{2} 2 \mathrm{KCl}$ 0.5: magnesium stycetol phesphate 0.5: Fe SO, 0.01: K.5O, 0.35 sucrusc, J0, aps, 12 and pH 6.3) were ased. The last medium mecived yeat eatnce 5 i $\mathrm{r}^{2}$

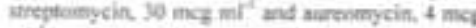
$\mathrm{ml}^{\prime}$ and the pHt was 40 for fling counting Nubzient beoth modiem wat used foe growing the belated hacteris and coetained (s I') septene, 5 heef eriract, 3 and pit 7.0

2.2. Samplea

The bugase wah watesuler sanples were collected in plastic tanks froen the paper pulp plast at Aswan during the wet stocage processt. The process flow diagran is presented in Fiens (i) (Covey et al, 2006). Aeroble compest (cow dung) used as sead was oteained from the Facadty of Apriculture, Cairo Univeniry. The acrotically Gigened sludee was oteained from the dometik wastewaler treatrent plant at Zenin. Gira Seed slowige wat incuhuted amobically for 24 b oxidine any organic maner that mighe be persene Inumabitived sells (polyseed. Poly huc carporntion. Belpium) were used for doe AOO, test

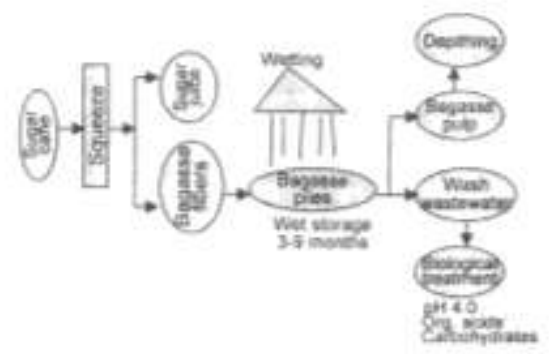

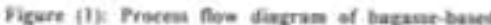

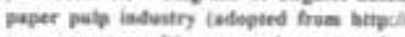

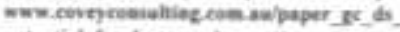

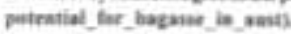

2.3. Isolation and identuficatioe of becteria trene bagases wash wastrwater

A notal of 21 tacterial colooies developed on afer plate momerating of either total acrobic of ceillublytic bacteria during the biological treatanem

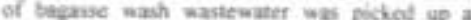
ravdon porified and maintained en munient ape slants. Identification of the holates was carried out acogonting to their morghological, cultural. physiological and biochemical chanacterivtics an deacribed in Aeroey's Manual of Determinutive 
Bacteriology (1994). Colony and cell morphology, Gram staining and catalase and oxidase reactions were determined as well.

\subsection{COD reduction}

Experiments were conducted either in 500$\mathrm{ml}$ Erlenmeyer flasks or in a double walled glass column of $14.5 \mathrm{~cm}$ diameter and $46.5 \mathrm{~cm}$ height coupled with a pump (L/S Easy-Load Pump Heads, Model MZ 7518-00 Cole-Parmer) with an aeration velocity of 2.25 Liters $\mathrm{min}^{-1}$. Flasks were shaken on a rotary shaker (Cole-Parmer, model 51704-25, USA) at $100 \mathrm{rpm}$ and the column was aerated continuously. At zero time and at every alternate day for a period of $5-17$ days, $2.5 \mathrm{ml}$ were withdrawn for COD analysis. To study the removal effect of aerobic compost microbial population and aerobic sludge on COD degradation, $50 \mathrm{ml}$ of seed aqueous compost solution filtrate were added to the column (wastewater initial $\mathrm{pH}$ 4.4). After 12 days of aerobic treatment, $20 \mathrm{ml}$ of seed aerobic sludge were added and the wastewater was treated for another 5 days. The effect of phosphorus and nitrogen addition on COD reduction was investigated by supplementation of the wastewater (the initial $\mathrm{pH}$ was adjusted to7.3) with $\mathrm{NH}_{4} \mathrm{Cl}$ (47.69 $\mathrm{mg} \mathrm{l}^{-1}$ ) and $\mathrm{K}_{2} \mathrm{HPO}_{4}\left(33.08 \mathrm{mg} \mathrm{l}^{-1}\right.$ ) and $5 \%$ $(\mathrm{v} / \mathrm{v})$ aerobic sludge. To investigate the influence of different nutrients concentrations, $\mathrm{NH}_{4} \mathrm{Cl}$ (23.13 and $76.93 \mathrm{mg} \mathrm{l}^{-1}$ ) and $\mathrm{K}_{2} \mathrm{HPO}_{4}(7.73$ and $46.2 \mathrm{mg} \mathrm{l}^{-1}$ ) were added to the wastewater supplemented with 5\% aerobic sludge. The effect of $\mathrm{pH}$ was studied by maintaining the $\mathrm{pH}$ at 7.0 by automatic addition of $\mathrm{NaOH}$ and $\mathrm{HCl}$ during the treatment process and initial seed sludge was 5\%. The ability of isolated bacteria to reduce the COD was monitored using a composite bacterial inoculant of members of Pseudomonas, Acinetobacter, Micrococcus, Bacillus, Aeromonas and 2 unidentified cultures. Cultures were grown each in $10 \mathrm{ml}$ nutrient broth for $24 \mathrm{~h}$, mixed together in equal portions, inoculated $(5 \% \mathrm{v} / \mathrm{v})$ into $120 \mathrm{ml}$ wastewater supplemented with nitrogen (final conc. $40 \mathrm{mg} \mathrm{l}^{-1}$ ) and phosphorus (final conc. $8 \mathrm{mg} \mathrm{l}^{-1}$ ) and incubated for 7 days. To investigate the effect of different sludge concentrations, 5, 10 and $20 \%$ aerobic sludge were added to wastewater received the same nutrients. After 7 days of treatment with the composite inoculant or $5 \%$ sludge, $10 \mathrm{ml}$ of the wastewater-cell mixture were re-inoculated into $120 \mathrm{ml}$ raw wastewater containing the same nutrients and incubated for another 7 days. To examine the ability of natural microflora in bagasse wash wastewater for COD reduction, wastewater supplemented with nitrogen and phosphorus (initial $\mathrm{pH}$ 7.0) was incubated without addition of any inoculants. All experiments were carried out at $25{ }^{\circ} \mathrm{C}$. At the end of experiment, bacterial biomass was measured by centrifugation at $10000 \mathrm{rpm}$ for $10 \mathrm{~min}$ and dried at $105^{\circ} \mathrm{C}$ for $12 \mathrm{~h}$.

\subsection{Chemical analysis \\ 2.5.1. Determination of chemical oxygen demand}

Chemical oxygen demand (COD) was measured using the closed reflux, colorimetric method (APHA, 1992). The tubes and caps were washed with $20 \% \quad \mathrm{H}_{2} \mathrm{SO}_{4}$ before use. Sample fractions $(2.5 \mathrm{ml})$ were added into COD glass tubes and $1.5 \mathrm{ml}$ of digestion solution $(10.216 \mathrm{~g}$ $\mathrm{K}_{2} \mathrm{Cr}_{2} \mathrm{O}_{7}, 167 \mathrm{ml}$ conc. $\mathrm{H}_{2} \mathrm{SO}_{4}$ and $33 \mathrm{~g} \mathrm{HgSO}_{4}$ were added to $500 \mathrm{ml}$ distilled water and diluted to $1000 \mathrm{ml}$ ) was added. A volume of $3.5 \mathrm{ml}$ of sulfuric acid reagent (5.5 $\mathrm{g} \mathrm{Ag}_{2} \mathrm{SO}_{4}$ dissolved in 1 $\mathrm{kg}$ conc. $\mathrm{H}_{2} \mathrm{SO}_{4}$ ) was added down inside of tubes. The tubes were tightly sealed with screw caps, inverted each several times and placed in a COD block digester (model RS32, Fisher, Strasburg) preheated to $150{ }^{\circ} \mathrm{C}$ for $2 \mathrm{~h}$. Blank and standard solutions were treated with the same manner as well. After digestion, the tubes were allowed to cool to room temperature and inverted several times and allowed the solids to settle before measuring absorbance at $600 \mathrm{~nm}$ using spectrophotometer (Model 6300 Jenway). To prepare the calibration curve, five standards from potassium hydrogen phthalate solution with COD equivalents from 20 to $900 \mathrm{mg} \mathrm{O}_{2} / \mathrm{l}$ were prepared. The following linear equation was used to calculate the unknown COD: $y=a x+b$. The COD decrease was calculated by the difference between the initial COD of bagasse wash wastewater and the final COD after the biological treatment as a percentage (Gonzalez et al., 1997).

\subsubsection{Measurement of 5-days biological oxygen demand}

Biological oxygen demand $\left(\mathrm{BOD}_{5}\right)$ was measured according to APHA (1992) using narrow-mouth $\mathrm{BOD}_{5}$ bottles (Nirschmann EM, Germany) with a $300 \mathrm{ml}$ capacity and with glass stoppers. Using a wide-tip volumetric pipette, the wastewater samples were added to the bottles. Polyseed (Polybac corporation, Belgium) was added at the rate of $1.1 \mathrm{mg}$ seed/bottle. Bottles were filled with enough dilution water $(1 \mathrm{ml}$ each of phosphate buffer, $\mathrm{MgSO}_{4}, \mathrm{CaCl}_{2}$ and $\mathrm{FeCl}_{3}$ solutions/l of distilled water). The initial 
dissolved oxygen (DO) level was measured using a dissolved oxygen meter (model DO 100 series, Cole-Parmer). The bottles were then tightly sealed and incubated in the dark at $20^{\circ} \mathrm{C}$ for 5 days. After incubation, the final DO level was measured and the reduction in the amount of DO during incubation gave a measure of the $\mathrm{BOD}_{5}$. The following equation was used for calculation:

$$
\mathrm{BOD}_{5}(\mathrm{mg} / \mathrm{l})=\frac{(D 1-D 2)-(B 1-B 2) f}{P}
$$

where: $D 1=\mathrm{DO}$ of diluted sample immediately after preparation $\left(\mathrm{mg} \mathrm{l}^{-1}\right)$.

$D 2=$ DO of diluted sample after $5 \mathrm{~d}$ incubation at $20{ }^{\circ} \mathrm{C}\left(\mathrm{mg} \mathrm{l}^{-1}\right)$.

$P=$ decimal volumetric fraction of sample used.

$B 1=\mathrm{DO}$ of seed control before incubation $\left(\mathrm{mg} \mathrm{l}^{-1}\right)$. $B 2=$ DO of seed control after incubation $\left(\mathrm{mg} \mathrm{l}^{-1}\right)$.

$f=$ ratio of seed in diluted sample to seed in seed control $=(\%$ seed in diluted sample $) /(\%$ seed in seed control).

\subsubsection{Nitrogen, phosphorus, ash, TSS and pH determinations}

Total nitrogen was determined by Kjeldahel method (AOAC, 1995) while analysis of $\mathrm{NO}_{3}-\mathrm{N}$ according to Cataldo's method (Cataldo et al., 1975). Phosphorus was determined using photometric method according to AOAC (1995). Ash content was determined by ignition of ovendried $\left(105^{\circ} \mathrm{C}\right)$ samples at $600{ }^{\circ} \mathrm{C}$ for $3 \mathrm{hrs}$ in a temperature-controlled muffle furnace (AOAC, 1995). Measurement of $\mathrm{pH}$ was done using a standard $\mathrm{pH}$ glass electrode (Jenway, model 3020, UK). Total solids (TS) were determined by drying the sample at $105{ }^{\circ} \mathrm{C}$ for $12 \mathrm{~h}$. Total suspended solids (TSS) were estimated according to APHA (1999) as follows: a well-mixed sample was filtered, the residue retained on the filter was dried to a constant weight at $105^{\circ} \mathrm{C}$ and the TSS was calculated from the following equation: $\mathrm{mg} / \mathrm{l}$ TSS $=[(A-B) \times 1000] /$ sample ml where $A$ equals the weight of the filter plus the residue $(\mathrm{mg})$ and $B$ equals the weight of the filter $(\mathrm{mg})$.

\section{RESULTS AND DISCUSSION \\ 3.1.Chemical and microbiological characterization of bagasse wash wastewater}

Table (1) summarizes the chemical and microbiological analyses of the examined bagasse wash wastewater. The wastewater was characterized by low $\mathrm{pH}(4.6 \pm 0.2)$. The high volatile fatty acid concentrations of $500-3500 \mathrm{mg}$ $1^{-1}$ and low $\mathrm{pH}$ of 4.5-5.5 are among the unique characteristics of bagasse wash wastewater (Chinnaraj and Venkoba, 2006). When bagasse is received from the sugar mill, it carries around 3$4 \%$ of residual sugars and during the storage these sugars are converted into organic acids by anaerobic microbial reactions that take place in the bagasse piles (Salabar and Maza, 1971). These organic acids reduce the $\mathrm{pH}$ in bagasse pile and preserve the bagasse quality, and get washed away during bagasse washing before pulping. Also, bagasse is stored in the wet condition by sprinkling the water over the pile to prevent degradation and fire hazard. The organic acids present in the pile get oozed out and join the bagasse wash wastewater and increase the volatile fatty acids content and reduce $\mathrm{pH}$ (Chinnaraj and Venkoba, 2006). Because of the fundamental relationship that exists between levels of $\mathrm{pH}$, it was important to include this parameter in the standard for industrial effluents. The average value for chemical oxygen demand (COD) content recorded up to 2009 (filtered) or 3472 (unfiltered) $\mathrm{mg} \mathrm{l}^{-1}$. Low strength wastewaters are those with COD below $2000 \mathrm{mg} \mathrm{l}^{-1}$ (Kato et al., 1994). Consequently, the examined bagasse wash wastewater is considered a high strength wastewater. The 5-days biological oxygen demand $\left(\mathrm{BOD}_{5}\right)$ reached 1838 (filtered) and 2700 (non filtered) $\mathrm{mg} \mathrm{l}^{-1}$ representing a $\mathrm{BOD}_{5} / \mathrm{COD}$ ratios of 0.92 and 0.78 , respectively. The BOD test is very useful in determining the strength of industrial wastewater pollutants, in terms of oxygen that is required when discharged in natural water courses. It is also greatly useful in assessing the performance of industrial wastewater treatment plants. The wastewater produced from pulp mill contains suspended solids, carbohydrates and lignin with $\mathrm{COD}$ and $\mathrm{BOD}_{5}$ of 76000 and $25000 \mathrm{mg} \mathrm{l}^{-1}$, respectively (Gray, 1989). Hunt and Pretorius (2000) reported the following quality parameters of the waste water produced from bagasse-based pulp and paper mill $\left(\mathrm{mg} \mathrm{l}^{-1}\right)$ : total COD, 7775-15775 and TSS, 10245228). Lower values of suspended solids (400$1000 \mathrm{mg} \mathrm{l}^{-1}$ ) and soluble COD (2000-7000 $\mathrm{mg} \mathrm{l}^{-1}$ ) were recorded by Chinnaraj and Venkoba (2006). With respect to growth nutrients, the bagasse wash wastewater contained $20.1 \mathrm{mg} \mathrm{l}^{-1}$ total nitrogen and $2 \mathrm{mg} \mathrm{l}^{-1}$ of phosphorus, which represent a poor COD: N: P ratio of 1004.5: 10: 1.0. No nitrate- $\mathrm{N}$ traces could be detected in the wastewater. The bagasse wash wastewater 
contained $457 \mathrm{mg}^{-1}$ total suspended solids. The amount of suspended solids determines the need for, and design of primary sealing-tanks in plants employing biological treatment processes. The numbers of microflora were relatively low (cfu $\mathrm{ml}^{-1}$ : total aerobic counts, $3.8 \times 10^{3}$ and cellulytic bacteria, $1.5 \times 10^{2}$ ). Examination of the colonies developed on the nutrient agar plates revealed that the Gram-negative short rods and Gram-positive spore-forming bacteria predominated other groups (each $35.3 \%$ ). Other groups included yeasts (17.6 $\%)$, molds (5.9\%) and Gram-positive cocci (5.9 $\%)$ as shown in Table (1).

\subsection{Time course of COD reduction in bagasse wash wastewater}

During the first day of treatment, no remarkable decrease in the COD content was observed (Table, 2). This might be attributed to the acidic reaction of the wastewater $(\mathrm{pH} 4.40$ 4.54). Acidification of a whey-containing wastewater was found to be the rate limiting step in the COD reduction (Kato et al., 1994). The microbial populations remained almost without considerable change. As the $\mathrm{pH}$ rose (from 4.54 to 7.24) after 3 days, the microbial population doubled around 6 times and the COD content decreased by $76.2 \%$ representing $882 \mathrm{mg}$ COD removed per liter and day. Further treatment of the wastewater up to 7 days resulted in only a slight decrease $(4.5 \%)$ of COD. Re-inoculation of the column with aerobic sludge led to $9.1 \%$ more COD reduction after 17 days. Up to this time, $89.8 \%$ of the COD was degraded. Aerobic treatment of bagasse wash wastewater greatly reduced its carbon content. After the aerobic treatment, the $\mathrm{pH}$ rose to 8.78 . However, the COD decrease continued indicating that this alkaline $\mathrm{pH}$ was not inhibitory to the microorganisms which were able to digest more carbon. A similar trend was noticed in experiments on bagasse based pulp and paper mill carried out by Hunt and Pretorius (2000) who reported an increase of $\mathrm{pH}$ to 9.0 during the aerobic treatment process. This might be due to the formation of ammonium through the microbial activities which was not further oxidized to nitrate probably due to the absence or inhibition of the nitrifying bacteria since nitrate was not detected. Chinnaraj and Venkoba (2006) suggested that the increase in $\mathrm{pH}$ and alkalinity during anaerobic treatment of bagasse wash wastewater was good indication that most of the organic compounds were converted into $\mathrm{CH}_{4}$ and $\mathrm{CO}_{2}$.

\subsection{Time course of COD reduction in bagasse wash wastewater after addition of phosphorus and nitrogen}

The calculated COD: $\mathrm{N}$ : $\mathrm{P}$ ratio in the bagasse wash wastewater was estimated as 1004.5: 10.1: 1. The ratio required for industrial wastewater treatment varies, depending on the wastewater type and the microorganisms used. Ratios of 1000: 13: 1 (malt whisky distilleries; Brown et al., 1976), 100: 10: 2 (molases; Kargi and Eylisleyen, 1995) and 900: 5: 1.7 (olive mill wastewater; Dirk et al., 2002) were applied. In the present study, the ratio was modified through the addition of $12.5 \mathrm{mg} \mathrm{l}^{-1}$ nitrogen (total concentration $32.6 \mathrm{mg} \mathrm{l}^{-}$ ${ }^{1}$ ) and $6 \mathrm{mg} \mathrm{l}^{-1}$ phosphorus (total concentration 8 $\mathrm{mg}^{-1}$ ) to the wastewater (unfiltered COD: $\mathrm{N}: \mathrm{P}=$ 1306: 12.3: 3) (filtered $=759.3: 12.3: 3$ ) at initial $\mathrm{pH}$ of 7.3. Such modification accelerated the COD decrease, where more than $95 \%$ of COD reduction was achieved after 5 days (Table, 3 ).

This efficiency was 1.3 fold more than that obtained without addition of nitrogen and phosphorus. The biomass produced after 5 days was $0.191 \mathrm{~g} \mathrm{l}^{-1}$ representing $0.073 \mathrm{~g}$ dry cells $/ \mathrm{g}$ COD removed. The 5-days biological oxygen demand $\left(\mathrm{BOD}_{5}\right)$ content dropped from initial 2700 $\mathrm{mg} \mathrm{l}^{-1}$ to $148.9 \mathrm{mg} \mathrm{l}^{-1}$ in the effluent, indicating that the remained COD $\left(188 \mathrm{mg} \mathrm{l}^{-1}\right)$ in the supernatant after separation of the cells represented biodegradable carbon and not microbial cells. Total suspended solids (TSS) dropped to $40.7 \mathrm{mg} \mathrm{l}^{-1}$ which corresponded $8.9 \%$ of that of the influent and representing $91.1 \%$ reduction efficiency due to the entrainment and digestion of solids by the activated sludge. Of particular significance, is that TSS were reduced to $1.2 \%$ of the initial COD value as was recommended (less than 10\%) for UASB reactors by Lettinga and Hulshoff (1991). Studies conducted by Hunt and Pretorius (2000) with wastewater from bagasse-based pulp and paper mill showed $93 \%$ TSS reduction in an aerobic reactor and final TSS of $c a .165 \mathrm{mg} \mathrm{l}^{-1}$ which corresponded to $c a .1 .4 \%$ of the initial COD. They suggested that some tertiary treatments would be required to lower the TSS levels to the recommended $50 \mathrm{mg}^{-1}$ for spray applications. All biological treatment processes employed by environmental engineers are dependent upon the reproduction of organisms involved in the treatment process. In planning wastewater treatment facilities it becomes important to know whether the wastewater contains sufficient quantities of nitrogen and phosphorus for the 
Table (1): Chemical and microbiological characteristics of bagasse wash wastewater.

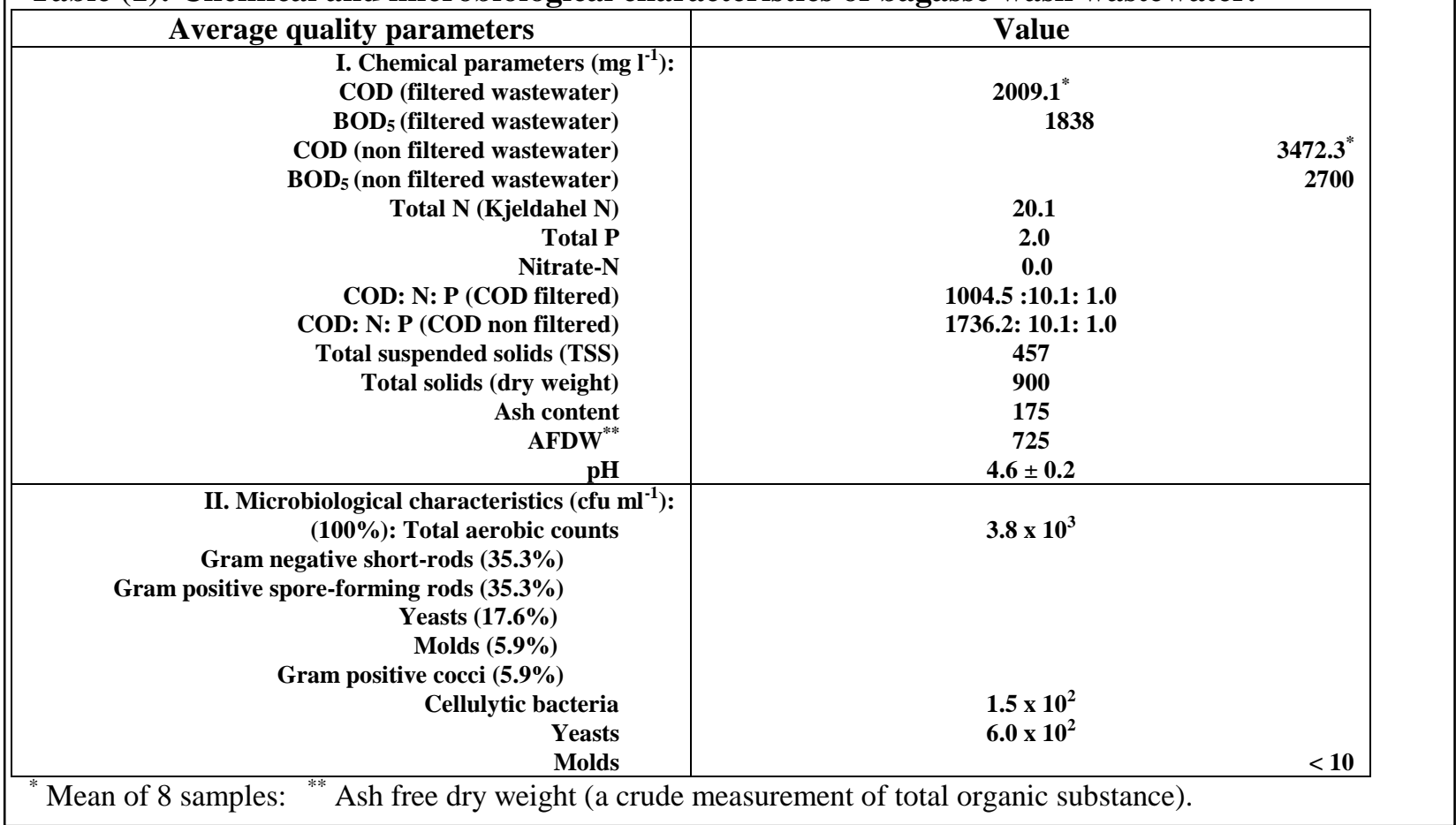

\section{Table (2): Time course of COD reduction in bagasse wash wastewater * .}

\begin{tabular}{||r|r|c|c|c|c|c|c|}
\hline \multirow{2}{*}{$\begin{array}{c}\text { Time } \\
\text { (days) }\end{array}$} & \multicolumn{2}{|c|}{ COD remained (non filtered) } & & \multicolumn{3}{|c|}{ Microbial counts $\left(\mathrm{cfu} \mathrm{ml}^{-1}\right.$ ) } \\
\cline { 2 - 8 } & $\mathrm{mg} \mathrm{l}^{-1}$ & $\%$ & $\mathrm{pH}$ & $\begin{array}{c}\text { Total aerobic } \\
\text { bacteria }\end{array}$ & $\begin{array}{c}\text { Cellulytic } \\
\text { bacteria }\end{array}$ & Yeasts & Molds \\
\hline 0 & 3472.3 (compost addition) & 100 & 4.40 & $4.0 \times 10^{4}$ & $1.2 \times 10^{2}$ & $1.9 \times 10^{4}$ & $<10$ \\
1 & 3450.1 & 99.4 & 4.54 & $3.0 \times 10^{4}$ & $3.6 \times 10^{2}$ & $<10$ & $<10$ \\
3 & 826.4 & 23.8 & 7.24 & $2.6 \times 10^{5}$ & $2.8 \times 10^{2}$ & $<10$ & 12 \\
5 & 815.3 & 23.5 & 8.27 & $2.0 \times 10^{6}$ & $5.8 \times 10^{3}$ & $6.1 \times 10^{2}$ & 18 \\
7 & 650.7 & 18.7 & 8.78 & & & & \\
12 & 670.1 (sludge addition) & 19.3 & & & & & \\
15 & 470.8 & 13.6 & & & & & \\
17 & 354.3 & 10.2 & & & & & \\
\hline
\end{tabular}

COD non filtered 3472.3 (COD: N: P 1736.2: 10.1: 1.0); total N, $20.1 \mathrm{mg} \mathrm{l}^{-1}$; total P, $2 \mathrm{mg} \mathrm{l}^{-1}$.

Table (3): Time course of COD reduction in bagasse wash wastewater after addition of $\mathrm{N}$ and $\mathrm{P}$ at initial $\mathrm{pH}$ of 7.3.

\begin{tabular}{|c|c|c|c|c|c|c|c|c|c|}
\hline \multirow[b]{2}{*}{ Time } & \multicolumn{2}{|c|}{$\operatorname{COD}\left(\mathrm{mg} \mathrm{l}^{-\mathbf{1}}\right)$} & \multirow{2}{*}{$\begin{array}{l}\text { BOD }_{5} \\
\left(\mathrm{mg} \mathrm{l}^{-1}\right)\end{array}$} & \multirow{2}{*}{$\begin{array}{c}\text { TSS } \\
\left(\mathrm{mg} \mathrm{l}^{-1}\right)\end{array}$} & \multirow[t]{2}{*}{ pH } & \multirow{2}{*}{$\begin{array}{c}\mathrm{NO}_{3}^{-} \\
\left(\mathrm{mg} \mathrm{l}^{-1}\right)\end{array}$} & \multicolumn{2}{|c|}{ Microbial counts $\left(\mathrm{cfu} \mathrm{ml}^{-1}\right)$} & \multirow{2}{*}{$\begin{array}{l}\text { Biomass } \\
\left(\mathrm{g} \mathrm{l}^{-1}\right)^{* * *}\end{array}$} \\
\hline & Non-filtered & Filtered & & & & & $\begin{array}{c}\text { Total } \\
\text { aerobic } \\
\text { bacteria }\end{array}$ & $\begin{array}{l}\text { Cellulytic } \\
\text { bacteria }\end{array}$ & \\
\hline o h & $3482.0(100)^{*}$ & $2025(100)$ & 2700 & 457 & 7.3 & $\mathbf{0}$ & $9.1 \times 10^{4}$ & $4.8 \times 10^{2}$ & - \\
\hline $5 \mathrm{~h}$ & $2635.9(75.7)$ & - & - & - & - & - & - & - & - \\
\hline $20 \mathrm{~h}$ & $2402.6(69.0)$ & $1354.7(66.9)$ & - & - & - & - & - & - & - \\
\hline $26 \mathrm{~h}$ & $2225.0(63.9)$ & $1354.7(66.9)$ & - & - & 8.6 & $\mathbf{0}$ & $1.7 \times 10^{8}$ & $6.2 \times 10^{5}$ & - \\
\hline $46 \mathrm{~h}$ & - & $1354.7(66.9)$ & - & - & 9.0 & $\mathbf{0}$ & $1.1 \times 10^{7}$ & $8.4 \times 10^{4}$ & - \\
\hline 3 d & $454.2(18.3)$ & $336.2(16.6)$ & 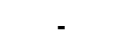 & - & 9.1 & $\mathbf{0}$ & $2.2 \times 10^{7}$ & $1.2 \times 10^{5}$ & - \\
\hline $4 \mathrm{~d}$ & $550.2(15.8)$ & $279.5(13.8)$ & - & - & 9.5 & $\mathbf{0}$ & $1.6 \times 10^{7}$ & $1.1 \times 10^{5}$ & - \\
\hline $5 \mathrm{~d}$ & $188.0(5.4)$ & $216.7(10.7)$ & 148.9 & 40.7 & 9.5 & $\mathbf{0}$ & $9.2 \times 10^{7}$ & $1.2 \times 10^{5}$ & 0.191 \\
\hline
\end{tabular}

*Values between brackets are percentages COD remained; total $\mathrm{N}, 32.6 \mathrm{mg} \mathrm{l}^{-1}$; total P, $8.0 \mathrm{mg} \mathrm{l}^{-1}$; COD: N: P = 435.3: 4.1: 1.0 (non filtered); $\mathrm{COD}: \mathrm{N}: \mathrm{P}=253.1: 4.1: 1.0$ (filtered); -, not determined.

**Dry weight. 
inicowingatien. The impirtant qoestions an mutrient ration, e. C.N and C.P ration, have beer

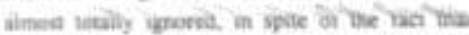
indestrial watewaters are frequestly deficient in mitropen and of phospherus as far an the inistorial mowth is concerned. The phovinological pereutial of mierebes dependa ae their ability no bymbesize enpmes that modiate sulatrate hiodeyrudation, Earyme vymtheais is a function of its availabiifity of a nithugen soorce

34. Effert of different cencentratienas of phespherus and miarezen en COD rentuctioa efficiency

The hiphest drups ie COD coscentratioe of 12.5 and $70.2 \%$ were achieved after 2 days of

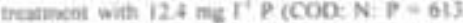

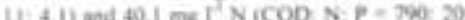
4), respectively (Talite 4 and 5 . This evincided wh the increase in total microbial pepulation

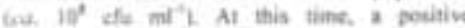
comviation was ohiained between pervatages of Cob reduxgian and bech $P$ and $N$ concentrsion (figure. 21 lianser $(16 \mathrm{~W}$ ) reperted that a BOO. *. 7 matie of 100; $\$$, 1 mas ideal fine growth and irratunest prucena.

3.5. Time ceurse af COD reduction in bagasse wash vastewater afher additien of phospharus and nitrogen at centrolled newiral pli

Maintainine the pHt constant within a range of 7.9 during the treaiment resulted in acreleration of the COD meduction 16.68 .25 ,

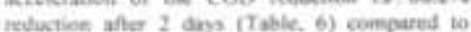

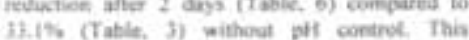
$33.1 \%$ (Tatile, H) without of controc. Thin indicales that neutralization of pli favored the bucterial vousth since at that time the wotal 41 and 16.7 fold hicher than those without pot comtrol, respoctively. Affer 5 days the acrobic tratinont rediesed the 000 wo 943 me $\mathrm{r}^{\prime}$ (os. 97 . meduction) confirming the claima in the liseration that anobic treatment was noquired to

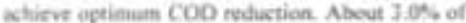
COP in the waterealer remained withent degrataion in the effluient and $14.7 \%$, of the inisid $C O O$ was converted to biomass $(0.3 \mathrm{~g}$ dr?

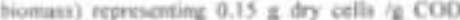
remered. The remainieg $124 \mathrm{~s}$ wn appartraty cenvened is $\mathrm{CO}$. The BoD. cament of the efleces itropped to 94.4 me $\mathrm{r}^{\prime}$, which earregonded to 2.45 , of that of the influtent and $92.0 \%$ af the final $\mathrm{COO}$ and representing a mefoction eficiency of in t5. The atserved desrease efficiensy was higher than that obtained by Hunt and Detorias (2000) with wastenater tros hagessebased polp and paper mill who

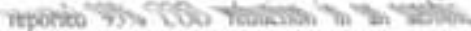
reacas. In a watcouter, the pit has a specia significance in the setese that, it wat be controlled within a rane favorable io particulas organisms involved. The hionasis fonmed after dres in the preaget atuty was 16 fold hicher thas that witheut pti comtrsl. Thit favons ise proposed hypothesia that the eflective wattesces biodegradation being a prowth asociated prucesia
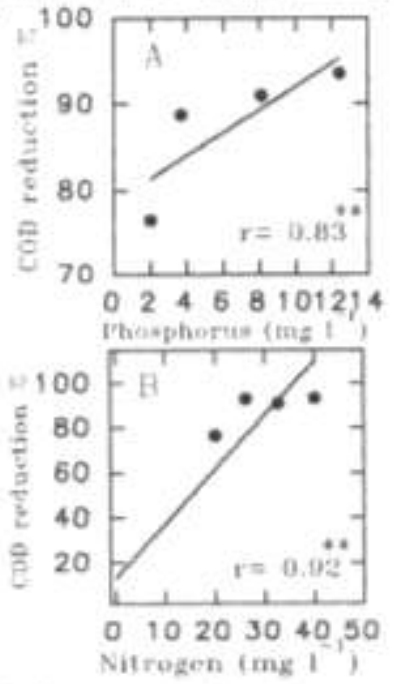

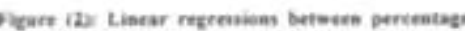
COP rufuction wed bath phoneberus (A) and natrugen (il) cunceatratien.

3.6. belation and identification of bacteria from bagatne wah wastewater

Dering the tine coune of biolongical treatment of bagase wash watcenater, different hackeria were bolated and identified to investigate the prodeminant candidates thas ape capoble of erowing under auch sonditioms and to lear their

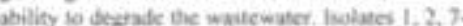
11 and 13-21 were obtained fruet plate inoculated by dilutions of watorwater of pit 9.0 Results of the identifkation are summariand is Iable for. A tetal of 21 bacterial cultures no ebtained. Thinteen ( biv s) 
Table (4): Time course of COD reduction in bagasse wash wastewater as affected by different nitrogen concentrations (26.1, 32.6 and $40.1 \mathrm{mg} \mathrm{l}^{-1}$ ) (initial $\mathrm{pH}$ of 6.7).

\begin{tabular}{|c|c|c|c|c|c|c|c|c|c|c|c|c|}
\hline \multirow{3}{*}{$\begin{array}{l}\text { Time } \\
\text { (days) }\end{array}$} & \multirow{2}{*}{\multicolumn{3}{|c|}{$\mathrm{COD}\left(\mathrm{mg} \mathrm{l}^{-1}\right)$ (filtered) }} & \multirow{2}{*}{\multicolumn{3}{|c|}{$\mathrm{pH}$}} & \multicolumn{6}{|c|}{ Bacterial counts $\left(\mathrm{cfu} \mathrm{ml}^{-1}\right)$} \\
\hline & & & & & & & \multicolumn{3}{|c|}{ Total aerobic bacteria } & \multicolumn{3}{|c|}{ Cellulytic bacteria } \\
\hline & $\begin{array}{c}26.1 \\
\mathrm{~N}\end{array}$ & $\begin{array}{c}32.6 \\
\mathrm{~N}\end{array}$ & $\begin{array}{c}40.1 \\
\mathrm{~N}\end{array}$ & $\begin{array}{c}26.1 \\
\mathrm{~N}\end{array}$ & $\begin{array}{c}32.6 \\
\mathrm{~N}\end{array}$ & $\begin{array}{c}40.1 \\
\mathrm{~N}\end{array}$ & $\begin{array}{c}26.1 \\
\mathrm{~N}\end{array}$ & $\begin{array}{c}32.6 \\
\mathrm{~N}\end{array}$ & $\begin{array}{c}40.1 \\
\mathrm{~N}\end{array}$ & $\begin{array}{c}26.1 \\
\mathrm{~N}\end{array}$ & $\begin{array}{c}32.6 \\
\mathrm{~N}\end{array}$ & $\begin{array}{c}40.1 \\
\mathrm{~N}\end{array}$ \\
\hline 0 & $1615(100)$ & $1597.7(100)$ & $1580.5(100)$ & 6.7 & 6.7 & 6.7 & $9.5 \times 10^{4}$ & $9.5 \times 10^{4}$ & $9.5 \times 10^{4}$ & $3.3 \times 10^{2}$ & $3.3 \times 10^{2}$ & $3.3 \times 10^{2}$ \\
\hline 1 & $1619.3(100.3)$ & $1653.8(103.5)$ & $1481.1(93.7)$ & 8.1 & 8.0 & 8.1 & $6.1 \times 10^{7}$ & $9.5 \times 10^{7}$ & $1.1 \times 10^{8}$ & $8.0 \times 10^{5}$ & $2.4 \times 10^{6}$ & $4.2 \times 10^{6}$ \\
\hline 2 & $773(47.9)$ & $980.2(61.4)$ & $470.7(29.8)$ & 8.3 & 7.9 & 8.4 & $2.0 \times 10^{7}$ & $3.7 \times 10^{7}$ & $7.3 \times 10^{7}$ & $1.1 \times 10^{6}$ & $1.9 \times 10^{6}$ & $1.9 \times 10^{6}$ \\
\hline 3 & $504.2(31.2)$ & $240.5(15.1)$ & $249.6(15.8)$ & 8.2 & 8.5 & 8.1 & $1.6 \times 10^{7}$ & $7.9 \times 10^{7}$ & $4.5 \times 10^{7}$ & $2.5 \times 10^{5}$ & $7.7 \times 10^{5}$ & $2.9 \times 10^{5}$ \\
\hline 4 & $152.9(9.5)$ & $295.7(18.5)$ & $214.4(13.6)$ & 8.6 & 8.3 & 8.3 & $1.4 \times 10^{7}$ & $2.5 \times 10^{7}$ & $4.3 \times 10^{7}$ & $2.6 \times 10^{5}$ & $6.0 \times 10^{5}$ & $2.8 \times 10^{5}$ \\
\hline 5 & $116.6(7.2)$ & $143.9(9.0)$ & $106.3(6.7)$ & 8.9 & 8.7 & 8.7 & & & & & & \\
\hline 6 & - & $51.3(3.2)$ & $101.9(6.5)$ & 8.9 & 8.8 & 8.9 & & & & & & \\
\hline
\end{tabular}

Total phosphorus concentration in all treatments is $8.1 \mathrm{mg} \mathrm{l}^{-1}$.

Table (5): Time course of COD reduction in bagasse wash wastewater as affected by different phosphorus concentrations $(3.7,8.1$ and $12.4 \mathrm{mg} \mathrm{l}^{-1}$ ) (initial $\mathrm{pH}$ of 6.7).

\begin{tabular}{|c|c|c|c|c|c|c|c|c|c|c|c|c|}
\hline \multirow{3}{*}{$\begin{array}{l}\text { Time } \\
\text { (days) }\end{array}$} & \multirow{2}{*}{\multicolumn{3}{|c|}{$\operatorname{COD}\left(\mathrm{mg} \mathrm{l}^{-1}\right)$ (filtered) }} & \multirow{2}{*}{\multicolumn{3}{|c|}{$\mathrm{pH}$}} & \multicolumn{6}{|c|}{ Bacterial counts $\left(\mathrm{cfu} \mathrm{ml}^{-1}\right)$} \\
\hline & & & & & & & \multicolumn{3}{|c|}{ Total aerobic bacteria } & \multicolumn{3}{|c|}{ Cellulytic bacteria } \\
\hline & $3.7 \mathrm{P}$ & $8.1 \mathrm{P}$ & $12.4 \mathrm{P}$ & $\begin{array}{c}3.7 \\
P\end{array}$ & $\begin{array}{c}8.1 \\
P\end{array}$ & $\begin{array}{c}12.4 \\
\mathrm{P}\end{array}$ & $3.7 \mathrm{P}$ & $8.1 \mathrm{P}$ & $12.4 \mathrm{P}$ & $3.7 \mathrm{P}$ & $8.1 \mathrm{P}$ & $12.4 \mathrm{P}$ \\
\hline 0 & $2005.7(100)$ & $1597.7(100)$ & $1839.1(100)$ & 6.7 & 6.7 & 6.7 & $9.5 \times 10^{4}$ & $9.5 \times 10^{4}$ & $9.5 \times 10^{4}$ & $3.3 \times 10^{2}$ & $3.3 \times 10^{2}$ & $3.3 \times 10^{2}$ \\
\hline 1 & $1438.1(71.7)$ & $1653.8(103.5)$ & $1679.7(91.3)$ & 8.07 & 8.0 & 8.14 & $4.9 \times 10^{7}$ & $9.5 \times 10^{7}$ & $9.0 \times 10^{7}$ & $2.2 \times 10^{6}$ & $2.4 \times 10^{6}$ & $1.4 \times 10^{6}$ \\
\hline 2 & $874.5(43.6)$ & $980.2(61.4)$ & $522.5(17.5)$ & 8.28 & 7.9 & 8.04 & $6.2 \times 10^{7}$ & $3.7 \times 10^{7}$ & $1.0 \times 10^{8}$ & $8.0 \times 10^{5}$ & $1.9 \times 10^{6}$ & $1.4 \times 10^{6}$ \\
\hline 3 & $417.2(20.8)$ & $240.5(15.1)$ & $351.0(19.1)$ & 8.50 & 8.4 & 8.29 & $2.1 \times 10^{8}$ & $7.9 \times 10^{7}$ & $9.6 \times 10^{7}$ & $5.5 \times 10^{5}$ & $7.7 \times 10^{5}$ & $2.4 \times 10^{5}$ \\
\hline 4 & $439.3(21.9)$ & $295.7(18.5)$ & $202.6(11.0)$ & 8.83 & 8.26 & 8.67 & $1.2 \times 10^{8}$ & $2.5 \times 10^{7}$ & $4.4 \times 10^{7}$ & $7.0 \times 10^{5}$ & $6.0 \times 10^{5}$ & $2.1 \times 10^{5}$ \\
\hline 5 & $226.6(11.3)$ & $143.9(9.0)$ & $118.9(6.5)$ & 8.90 & 8.73 & 8.89 & & & & & & \\
\hline 6 & $110.3(5.5)$ & $51.3(3.2)$ & $168.4(9.2)$ & 8.91 & 8.7 & 9.0 & & & & & & \\
\hline
\end{tabular}

Total nitrogen concentration in all treatments is $32.6 \mathrm{mg} \mathrm{l}^{-1}$. 
Table (6): Time course of COD reduction in bagasse wash wastewater after addition of nitrogen and phosphorus as affected by $\mathrm{pH}$ control (constant $\mathrm{pH} 7$ )

\begin{tabular}{|c|c|c|c|c|c|}
\hline \multirow{2}{*}{$\begin{array}{r}\text { Time } \\
\text { (days) }\end{array}$} & \multirow{2}{*}{$\begin{array}{c}\mathrm{COD}\left(\mathrm{mg} \mathrm{l}^{-1}\right) \\
\text { (Filtered) }\end{array}$} & \multirow{2}{*}{$\begin{array}{l}\text { BOD }_{5} \\
\left(\mathrm{mg} \mathrm{l}^{-1}\right)\end{array}$} & \multicolumn{2}{|c|}{ Microbial counts (cfu ml ${ }^{-1}$ ) } & \multirow{2}{*}{$\begin{array}{c}\text { Biomass }{ }^{* *} \\
\left(\mathrm{~g} \mathrm{l}^{-1}\right)\end{array}$} \\
\hline & & & Total aerobic bacteria & Cellulytic bacteria & \\
\hline 0 & $2035(100)^{*}$ & 1888 & $7.7 \times 10^{4}$ & $2.1 \times 10^{3}$ & - \\
\hline 1 & $1818(89.3)$ & - & $4.5 \times 10^{7}$ & $4.5 \times 10^{5}$ & - \\
\hline 2 & $648(31.8)$ & - & $5.6 \times 10^{7}$ & $1.4 \times 10^{6}$ & - \\
\hline 3 & $193.6(9.5)$ & - & $7.9 \times 10^{6}$ & $7.5 \times 10^{4}$ & - \\
\hline 4 & $154.1(7.6)$ & - & - & $7.5 \times 10^{4}$ & - \\
\hline 5 & $59.3(2.9)$ & 54.9 & $1.8 \times 10^{6}$ & $1.0 \times 10^{3}$ & 0.3 \\
\hline
\end{tabular}

*Values between brackets are percentages of COD remained; total N, $32.6 \mathrm{mg} \mathrm{l}^{-1}$; total P, $8.0 \mathrm{mg} \mathrm{l}^{-1}$,

COD: N: $\mathrm{P}=254.4: 4.1: 1 ; * *$ Dry weight

Table (7): Morphological and biochemical characteristics of bacterial cultures isolated during biological treatment of bagasse wash wastewater

\begin{tabular}{|c|c|c|c|c|c|c|c|c|}
\hline \multirow{2}{*}{$\begin{array}{l}\text { Isolat } \\
\text { e No. }\end{array}$} & \multirow{2}{*}{$\begin{array}{l}\text { Isolate } \\
\text { d from }\end{array}$} & \multirow{2}{*}{$\begin{array}{c}\text { Colony } \\
\text { color }\end{array}$} & \multirow{2}{*}{$\begin{array}{c}\text { Motilit } \\
\mathbf{y}\end{array}$} & \multirow{2}{*}{$\begin{array}{c}\text { Catalas } \\
\text { e }\end{array}$} & \multirow{2}{*}{$\begin{array}{c}\text { Oxidas } \\
\text { e }\end{array}$} & \multicolumn{2}{|c|}{ Glucose } & \multirow{2}{*}{ Proposed genus } \\
\hline & & & & & & Oxidative & Fermentative & \\
\hline \multicolumn{9}{|c|}{ Gram negative short rods } \\
\hline 1 & Cel. plates & Gray & + & + & + & - & - & \\
\hline 2 & Cel. plates & Colorless & + & + & + & - & - & \\
\hline 3 & Cel. plates & Colorless & + & + & + & + & - & \\
\hline 4 & Cel. plates & Colorless & + & + & + & \pm & - & \\
\hline 5 & Cel. plates & Colorless & + & + & + & - & - & \\
\hline 6 & Cel. plates & Colorless & + & + & + & - & - & \\
\hline 7 & TC & Gray & + & + & + & + & - & \\
\hline 8 & TC & Gray & + & + & + & + & - & \\
\hline 9 & TC & Colorless & \pm & + & + & - & + & Aeromonas* \\
\hline 10 & TC & Gray & & + & + & + & - & \\
\hline 11 & TC & Colorless & + & + & + & + & $+($ gas $)$ & \\
\hline 12 & TC & Colorless & - & + & - & + & + & \\
\hline 13 & TC & Colorless & - & + & - & - & - & \\
\hline \multicolumn{9}{|c|}{ Gram negative non-spore-forming thin long rods } \\
\hline 14 & Cel. plates & Colorless & + & + & + & - & - & \\
\hline 15 & Cel. plates & Colorless & + & + & + & + & - & \\
\hline 16 & TC & Gray & + & + & - & - & - & \\
\hline 17 & TC & Gray & + & + & - & & - & \\
\hline 18 & TC & Colorless & + & + & + & - & - & \\
\hline \multicolumn{9}{|c|}{ Gram positive spore-forming rods } \\
\hline 19 & TC & & + & + & + & + & + & Bacillus** \\
\hline \multicolumn{9}{|c|}{ Gram positive coccus-shaped cells } \\
\hline 20 & TC & & - & + & - & + & + & Micrococcus $_{* *}^{* *}$ \\
\hline \multicolumn{9}{|c|}{ Gram positive oval-shaped cells } \\
\hline 21 & TC & & & + & - & + & - & \\
\hline \multirow{3}{*}{\multicolumn{2}{|c|}{$\begin{array}{l}\text { Morphological } \\
\text { and biochemical } \\
\text { tests }\end{array}$}} & \multicolumn{4}{|c|}{ Identification of Pseudomonas } & \multicolumn{3}{|c|}{ Identification of Acinetobacter } \\
\hline & & \multicolumn{4}{|c|}{ Characteristics of isolates } & \multicolumn{3}{|c|}{ Characteristics of isolates } \\
\hline & & 3 & 4 & 7 & 8 & 12 & 13 & \\
\hline $\begin{array}{l}\text { Cell sha } \\
\text { Motility } \\
\mathrm{O}_{2} \text { requ } \\
\text { Oxidase } \\
\text { O/F glu } \\
\text { Gelatin } \\
\mathrm{NO}_{3}^{-} \text {re } \\
\text { Starch h } \\
\text { Indol fr } \\
\text { tryptopl } \\
\text { Acid fro } \\
\text { Citrate }\end{array}$ & $\begin{array}{l}\text { pe } \\
\text { rement } \\
\text { test } \\
\text { ose test } \\
\text { hydrolysis } \\
\text { luction } \\
\text { ydrolysis } \\
\text { m } \\
\text { lan } \\
\text { m glucose } \\
\text { Itilization }\end{array}$ & $\begin{array}{c}\text { rods } \\
+ \\
\text { aerobic } \\
+ \\
+/- \\
+ \\
+ \\
-\end{array}$ & $\begin{array}{c}\text { rods } \\
+ \\
\text { aerobic } \\
+ \\
\pm /- \\
+ \\
+ \\
-\end{array}$ & $\begin{array}{c}\text { rods } \\
+ \\
\text { aerobic } \\
+ \\
+/- \\
+ \\
+ \\
-\end{array}$ & $\begin{array}{c}\text { rods } \\
+ \\
\text { aerobic } \\
+ \\
+/- \\
+ \\
+ \\
-\end{array}$ & $\begin{array}{c}\text { coccobacilli } \\
- \\
\text { aerobic } \\
- \\
+/- \\
- \\
- \\
\text { nd } \\
- \\
- \\
+\end{array}$ & $\begin{array}{c}\text { coccobacilli } \\
- \\
\text { aerobic } \\
- \\
-/- \\
- \\
- \\
\text { nd } \\
- \\
- \\
+\end{array}$ & \\
\hline
\end{tabular}

$(+)$, positive result; (-), negative result; \pm , weak result; nd, not determined; TC, total aerobic counts plates; rod-shaped cells are straight rods. *Mannitol (+); arginin dihydrolase (+); urease (-); gelatin hydrolysis $(+)$; $\mathrm{NO}_{3}{ }^{-}$reduction $(+)$.

**Gelatin hydrolysis (+); starch hydrolysis (+); casein hydrolysis $(+)$; acetyl methyl carbinol (+); citrate utilization $(+)$.

$* * * \mathrm{NO}_{3}{ }^{-}$reduction $(+)$; arginin hydrolysis $(-) ; 7.5 \% \mathrm{NaCl}$ not required for growth. 
bacterial isolates were microscopically necoenized an Girain megative mod shaped. They were further resognized inte two majof grougs; nos pignent producen and yroducen of diffuaible uray pigment. Four (30. is to) isolates out of 13 Gnum neyative rod shaped isoiates were fouind to beiong to the crnus Puradomonar. Two $(15.4 \%)$ isolates

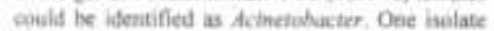
belonged to the genis Aeromoner. Cran positive apore-formieg rodi (mainly Bucithes) and Gram pesitive coccus-shaped cells (mainly Micniconcur) were isolated in low trequencies.

37. Abitity of isolated bacteria to degrade the hagase wash wastewater

Referring to the erological concept "the covifarment aelects", it was decided to spely an actively powing cumposite inoculant of memben

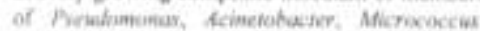
Becilhas, Aerumsinas and 2 unidentified culture The micrsoryanixma, when gnown in pure culiurs utiting the sarne auhairate conatituenas. whie of mikest cutture different consituents are uned by cach candidate, permitting "s stable ans complementary active popolation. Two wheyeen incocitation rums werz conducted in the now wastewater. in the ist nath the inecufant wa efficient in the $\mathrm{COD}$ reduction, since ca sogh of the COO was deyraded within I day (Tuble, N) floweves, this inoculant did not achieve the

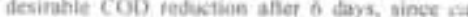
los of the $\mathrm{COO}$ - crutent remained Re inscielation (2nd no) of the stowing cells inte row wasurwater nesulted in 1, 5.34 more $\mathrm{CO}$ neduction and the reduction efficiency increased

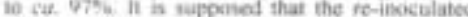
cells are mare acclimatized and consequenaly were more efficient.

3.8. Elfect of activated siader concestratien a. the COD redectian efliciesey

to velecd the mest aporopriate diufge quantity. there ceocentrations wre tested is s, 10 and 2uls. The highest COD nefuctions emeiencies were observed with $5 \%$ sludge (Table, 8) Howeref. afier 6 days of treatment, a peaitive eorvelation between shafue concentration and the persentaue of decrease was obtained (Figure. J) Re-inoculation of the grown cells into frest wastewater had no remarkabic effect on the COD rediction efficiency. Activatiod sludge appeated to he anove effective $(97.5 \%$ COD roduction after 6 days) than the holated composite innesium (6) $5 \times 6$.
Wattewater insubated without the addition of any inocularts had a poor desradation sctivity towath $C O D$. The $C O O$ decreased slowty and the reduction effieiency eatienated after 6 days wa $1.2+1.3$ fold lower than that with sludes of bacterial inciculant (Table:8), indicatioy the necessity of the addition of acclimatized micrsornanisus

Finally, it could be coneluded that the aerobie treatinent of the bugase wash wastewater might suxcessfulty refoce the oruanic loud to a

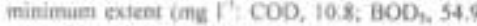
and TSS, 40.7 repirenenting reduction eflieiencie: of $99,4,97.1$ and 91.14 , reapectively ) which vuaruates a substantially parified effluent, it is

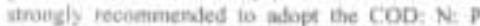
ratio of 1017: 16: 4 to secure the proper treatment The US finvimonenentai Protection Ayency (BPA. 1998) dentified best" fucitities on a BOD performance criteria of achieving a $95 \%$ BOo reduction of a $B O 0$ efficent level of 40 my $\}^{\prime}$ Accorting to the Egoptian guidelines (1994), the discharge criteria were (me $\mathrm{I}^{-1}$, $B O D$, 60 , $C O D$ 100 and TSS, 60. Wasiewater genetated froen bogase washing and from the bagase yant laving relatively hiah $\mathrm{COP}$ when compored to acher wastewaler foom bieach plant and paper machine, can be tueated by anaerobic prices. followed by aclivated shadige process. The anacrobic save lis orsdited for nmevine most of the COD while producine malles quastities of sludse than equivalens aerobic syvens, while the avrobic stage is capable of move omplete $\mathrm{COO}$ reduction. Another advantase of the aerobic over anservbic trealment is the conversing of exganic compounds to $\mathrm{CO}$ wbose ulobal warming potential is 21 thens less thas CH4OFCCC. 1996).

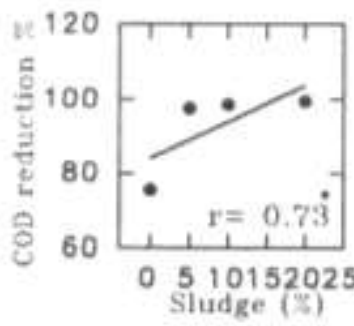

Figere (3) Liaear rogression betwaen percencage COB refuctien and studete concentratias. 
Table (8): Time course of COD reduction in bagasse wash wastewater using composite bacterial inoculant or different sludge concentrations (initial pH 7)

\begin{tabular}{|c|c|c|c|c|c|}
\hline \multirow{3}{*}{$\begin{array}{c}\text { Time (hours or } \\
\text { days) }\end{array}$} & \multicolumn{5}{|c|}{ COD $\left(\mathrm{mg} \mathrm{l}^{-1}\right)$ (Filtered) } \\
\hline & \multirow{2}{*}{$\begin{array}{l}\text { Composite } \\
\text { bacterial } \\
\text { inoculant }\end{array}$} & \multicolumn{3}{|c|}{ Sludge $(\%)$} & \multirow{2}{*}{$\begin{array}{c}\text { Without sludge or } \\
\text { bacterial } \\
\text { inoculation }\end{array}$} \\
\hline & & 5 & 10 & 20 & \\
\hline $\mathbf{1}^{\text {st }}$ inoculation run: & & & & & . \\
\hline 0 & $1829.1(100)$ & $1725.2(100)$ & $1806.8(100)$ & $1886.1(100)$ & $1934.3(100)$ \\
\hline 17 hour & $368(20.1)$ & $447.9(26)$ & $672.1(37.2)$ & $716.7(38)$ & $1108.4(57.3)$ \\
\hline 26 hour & $381.7(20.9)$ & $290.8(16.9)$ & $623.3(34.5)$ & $805.4(42.7)$ & $723.4(37.4)$ \\
\hline 42 hour & $326.5(17.9)$ & $203.3(11.8)$ & $616.1(34.1)$ & $386.7(20.5)$ & $524.2(27.1)$ \\
\hline 50 hour & $247(13.5)$ & $168.7(9.8)$ & $272.8(15.1)$ & $452.7(24)$ & $729.2(37.7)$ \\
\hline 3 days & $247(13.5)$ & $61.6(3.6)$ & $209.6(11.6)$ & $173.5(9.2)$ & $468.1(24.2)$ \\
\hline 4 days & - & - & $65.0(3.6)$ & $62.2(3.3)$ & $512.6(26.5)$ \\
\hline 6 days & $167.6(9.2)$ & $43.3(2.5)$ & - & $11.3(0.6)$ & $433.3(22.4)$ \\
\hline 7 days & - & $32.9(1.9)$ & $10.8(0.6)$ & - & $272.7(14.1)$ \\
\hline $2^{\text {nd }}$ inoculation run: & & & & & \\
\hline 0 & $1886.6(100)$ & $1802.8(100)$ & & & \\
\hline 1 day & $469.7(24.9)$ & $403.8(22.4)$ & & & \\
\hline 2 days & $277.3(14.7)$ & $248.8(13.8)$ & & & \\
\hline 3 days & $150.9(8.0)$ & $176.7(9.8)$ & & & \\
\hline 4 days & $84.9(4.5)$ & $155.0(8.6)$ & & & \\
\hline 5 days & $113.2(6.0)$ & $72.1(4.0)$ & & & \\
\hline 6 days & $58.5(3.1)$ & $45.1(2.5)$ & & & \\
\hline 7 days & - & $45.1(2.5)$ & & & \\
\hline
\end{tabular}

Values between brackets are percentages of remained COD; total $\mathrm{N}, 40 \mathrm{mg} \mathrm{l}^{-1}$ and total P, $8 \mathrm{mg} \mathrm{l}^{-1}$.

\section{REFERENCES}

AOAC (1995). Methods of Analysis. Association of Official Agriculture Chemists, $16^{\text {th }} \mathrm{ed}$, Washington DC, USA.

APHA (1992). Standard Methods for the Examination of Water and Wastewater, $18^{\text {th }}$ ed. Standard Method 5210. Franson A.D.E. (ed), American Public Health Association, NW, Washington, DC, USA.

APHA (1999). Standard Methods for the Examination of Water and Wastewater, Csuros M., Csuros C. (eds), American Public Health Association, NW, Washington, DC, USA.

Atchison J.E. (1971). Modern methods of purchasing, handling and storage of bagasse. Non-wood plant fibre pulping progress. Report no. 2. TAPPI Press; p. 5-29.

Atlas R.M. (1997). Handbook of Microbiological Media. $2^{\text {nd }}$ ed. Parkars L.C. (ed), CRC Press Inc. New York.

Bergey's Manual of Determinative Bacteriology (1994). John, G.H.; Noel, R.K.; Peter, H.A.;
Jamest, S. and Stanley, T.W. (eds.), $9^{\text {th }}$ edition.

Brown D., Mckay R. and Weir W. (1976). Some problems associated with the treatment of effluents from malt whisky distilleries. Prog. Water Technol. 8: 291-300.

Cataldo D.A., Haroon M., Schrader L.E. and Youngs V.L. (1975). Rapid colorimetric determination of nitrate in plant tissue by nitration of salycylic acid. Commun. of Soil Sci. and Plant Analysis 6(1): 71-80.

Chinnaraj S. and Venkoba G. (2006). Implementation of an UASB anaerobic digester at bagasse-based pulp and paper industry. Biomass and Bioenergy, 30:273-277.

Covey G., Rainey T. and Shore D. (2006). The potential for bagasse pulping in Australia. http://www.coveyconsulting com.au/paper _gc_ds_potential_for_bagasse_in_aust.

Dirk H., Apostolos N. and Xanthoulis D. (2002). Wastewater recylcling of olive mills in Mediterranean countries: demonstration and sustainable reuse of residuals. Project ICA3CT-1999-00011, Jülich, Germany. 
Egyptian guidelines (1994). Egyptian guidelines with respect to the environment's law. Act $\S 4$ (1994).

EPA (1998). Effluent Limitations Guidelines, Pretreatment Standards, and New Source Performance Standards for the Industrial Waste Combustor Subcategory of the Waste Combustors Point Source Category. 63(25): 6391-6423.

Ezz A.E. (2003). Growth of the Environment Market of Egypt Profitable Compliance, the Carrot not the Stick. EnviroEgypt S.A.E.

Gonzalez B.G., Pena M.M. and Santos D.R. (1997). Decholorization of wastewater from an alcoholic fermentation process with Trametes versicolor. Biores. Technol. 61: 33-37.

Gray N.F. (1989). Biology of Wastewater Treatment. Gray N.F. (ed), Oxford Univ. Press, Oxford.

Hamer G. (1990). Aerobic biotreatment: the performance limits of microbes and the potential for exploitation. Trans IChemE, Vol. 68, Part B.

Hunt N.A. and Pretorius W.A. (1999). Acidogenic treatment for coagulation of wastewater from a bagasse and wastepaper integrated fluting mill. TAPSA Journal, November. 1999.

Hunt N A. and Pretorius W. A. (2000). Application of pre-acidification in the biological treatment of wastewater from a bagasse based pulp and paper mill. TAPSA Journal, Septemper 2000.
IPCCC (1996). IPCCC Guidelines for National Greenhouse Gas Inventories. Reference Manual, UNFCC. Int.

Kargi F. and Eylisleyen S. (1995). Batch biological treatment of synthetic wastewater in a fluidized bed containing wire mesh sponge particles. Enzym. Microb. Technol. 17(2): 119123.

Kato M. T., Field J. A., Kleerebezem R. and Lettinga G. (1994). Treatment of low strength soluble wastewaters in UASB reactors. J. Ferment. Bioeng. 77(6): 679-686.

Kortikaas S., Doma H.S., Potapenko S.A., Field J.A. and Lettinga G. (1994). Sequenced anaerobic-aerobic treatment of Hemp Black Liquors. Wat. Sci. Tech. 29 (5-6): 409-419.

Lee J. W., Peterson D.L. and Stickney A.R. (1989). Anaerobic treatment of pulp and paper mill wastewaters, TAPPI Environmental Conference Proceedings. TAPPI Press, Atlanta.

Lettinga G. and Hulshoff L.W. (1991). UASBprocess design for various types of wastewaters. Water Sci. Tech. 24(8): 87-107.

Oxoid (1983). Hand Book of Oxoid for Microbiological Purposes. Oxoid, $\mathrm{GmbH}$, Germany.

Salabar J. and Maza F. (1971). Ritter treatment process for bagasse storage. Non-wood plant fibre pulping progress. Report no. 2 TAPPI Press, p. 51-78.

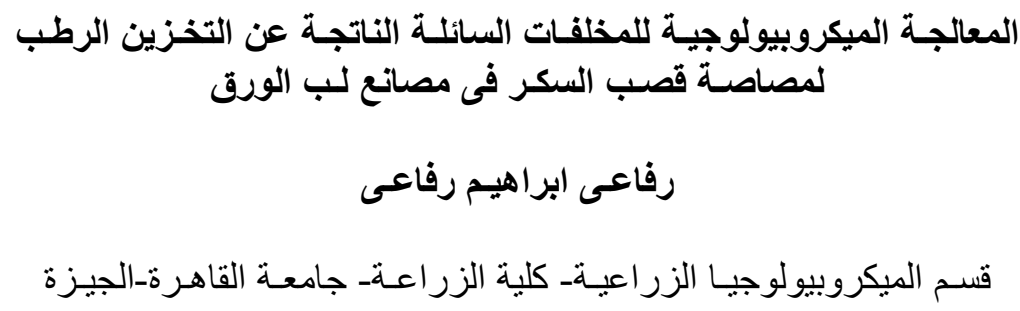

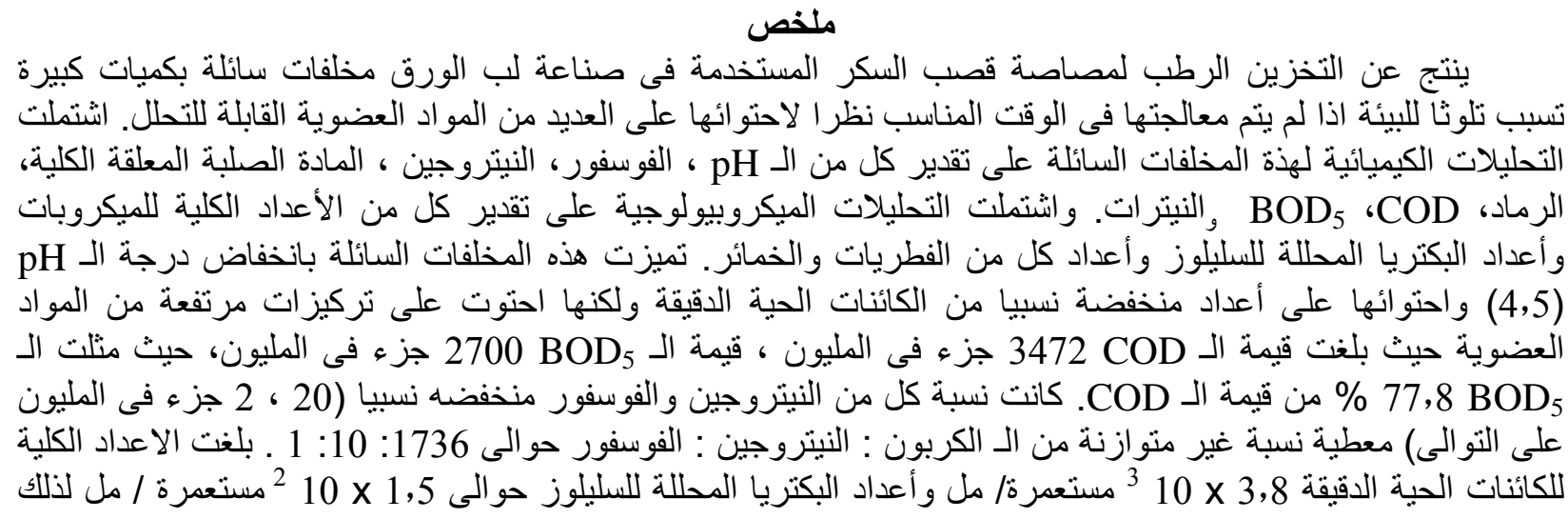


فقد نم دراسة أنسب الظروف البيئية لمعالجة هذه المخلفات ميكروبيولوجيا تحت الظروف الهوائية، وذللك باكثار أعداد

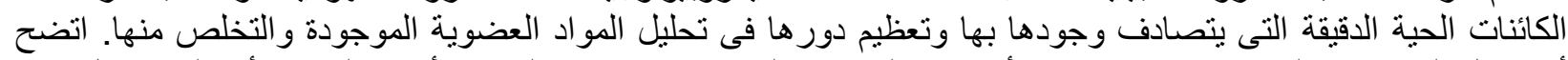

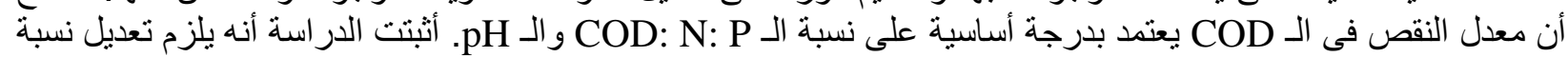

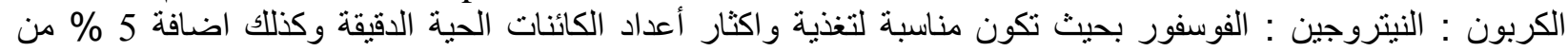
الحمأة النشطة المتأقلمة المتحصل عليها من محطات معالجة الصرف الصنية الصحى كمصدر خارجى للميكروبات. تحققت أفضل

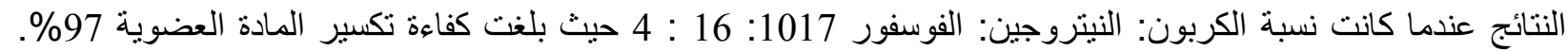

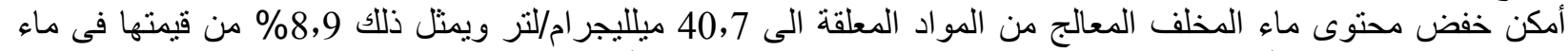

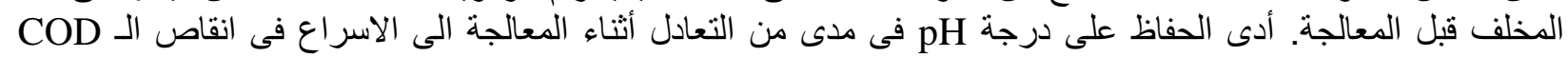

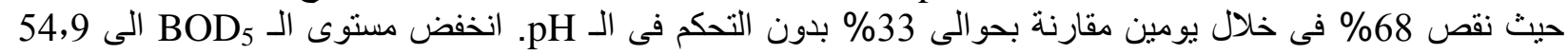

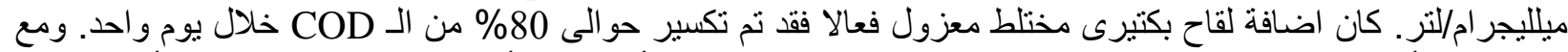

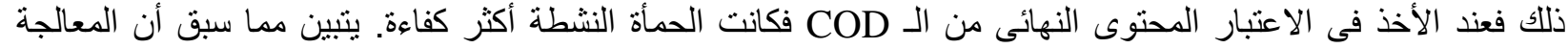

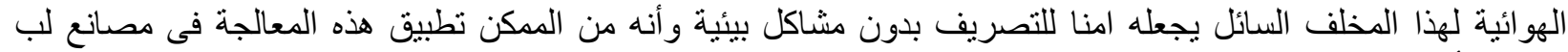

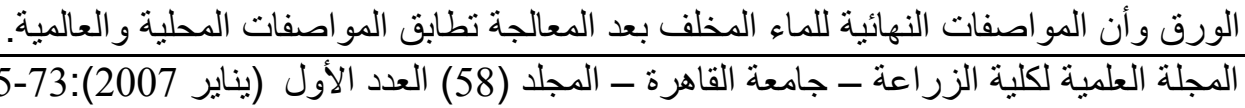

